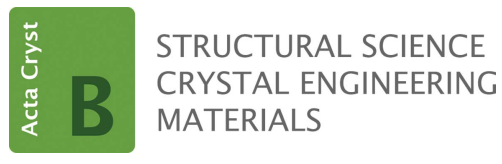

ISSN 2052-5206

Received 19 March 2018

Accepted 15 May 2018

Edited by J. Lipkowski, Polish Academy of Sciences, Poland

Keywords: nollmotzite; new mineral; uranium oxide fluoride; pentavalent uranium.

CCDC reference: 1843381

Supporting information: this article has supporting information at journals.iucr.org/b

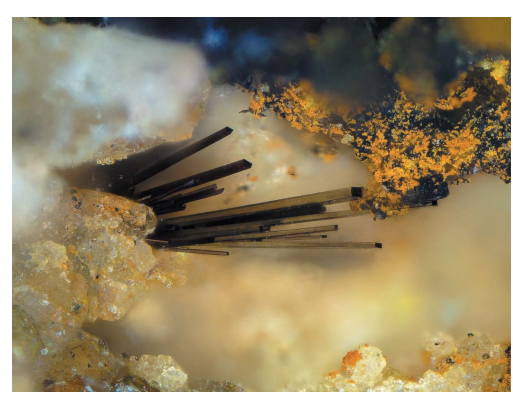

OPEN $\odot$ ACCESS

\section{Nollmotzite, $\mathrm{Mg}\left[\mathrm{U}^{\mathrm{V}}\left(\mathrm{U}^{\mathrm{VI}} \mathrm{O}_{2}\right)_{2} \mathrm{O}_{4} \mathrm{~F}_{3}\right] \cdot 4 \mathrm{H}_{2} \mathrm{O}$, the first natural uranium oxide containing fluorine}

\author{
Jakub Plášil, ${ }^{a *}$ Anthony R. Kampf, ${ }^{b}$ Radek Škodac $^{c}$ and Jiří Čejka ${ }^{d}$ \\ anstitute of Physics ASCR, v.v.i., Na Slovance 2, Praha 8, 18221, Czech Republic, bMineral Sciences Department, \\ Natural History Museum of Los Angeles County, 900 Exposition Boulevard, Los Angeles, CA 90007, USA, 'Department of \\ Geological Sciences, Faculty of Science, Masaryk University, Kotlářská 2, Brno, 61137, Czech Republic, and \\ dDepartment of Mineralogy and Petrology, National Museum, Cirkusová 1740, Prague 9, 19300, Czech Republic. \\ *Correspondence e-mail: plasil@fzu.cz
}

Nollmotzite (IMA2017-100), $\mathrm{Mg}\left[\mathrm{U}^{\mathrm{V}}\left(\mathrm{U}^{\mathrm{VI}} \mathrm{O}_{2}\right)_{2} \mathrm{~F}_{3} \mathrm{O}_{4}\right]\left(\mathrm{H}_{2} \mathrm{O}\right)_{4}$, is a new uranium oxide fluoride mineral found in the Clara mine, Black Forest Mountains, Germany. Electron microprobe analysis provided the empirical formula $\left(\mathrm{Mg}_{1.06} \mathrm{Cu}_{0.02}\right)_{\Sigma 1.08}\left[\mathrm{U}^{\mathrm{V}}\left(\mathrm{U}^{\mathrm{VI}} \mathrm{O}_{2}\right)_{2} \mathrm{O}_{3.85} \mathrm{~F}_{3.15}\right]\left[\left(\mathrm{H}_{2} \mathrm{O}\right)_{3.69}(\mathrm{OH})_{0.31}\right]_{\Sigma 4.00}$ based on three $\mathrm{U}$ and $15 \mathrm{O}+\mathrm{F}$ atoms per formula unit. Nollmotzite is monoclinic, space group $C m$, with $a=7.1015$ (12) $\AA, b=11.7489$ (17) $\AA, c=8.1954$ (14) $\AA, \beta=$ $98.087(14)^{\circ}, V=676.98(19) \AA^{3}$ and $Z=2$. The crystal structure [twinned by reticular merohedry; refined to $R=0.0369$ with $\mathrm{GoF}=1.09$ for 1527 unique observed reflections, $I>3 \sigma(I)]$ is based upon $\left[\mathrm{U}^{\mathrm{V}}\left(\mathrm{U}^{\mathrm{VI}} \mathrm{O}_{2}\right)_{2} \mathrm{~F}_{3} \mathrm{O}_{4}\right]^{2-}$ sheets of $\beta$ $\mathrm{U}_{3} \mathrm{O}_{8}$ topology and contains an interlayer with $\mathrm{MgF}_{2}\left(\mathrm{H}_{2} \mathrm{O}\right)_{4}$ octahedra. Adjacent sheets are linked through $\mathrm{F}-\mathrm{Mg}-\mathrm{F}$ bonds, as well as via hydrogen bonds. The presence of fluorine and pentavalent uranium in the structure of nollmotzite has potentially important implications for the safe disposal of nuclear waste.

\section{Introduction}

Uranium oxides, especially those containing $\mathrm{U}^{\mathrm{VI}}$ as the uranyl $\left(\mathrm{UO}_{2}{ }^{2+}\right)$ ion, are important products of supergene weathering of primary $\mathrm{U}^{\mathrm{IV}}$ minerals, predominantly uraninite, $\mathrm{UO}_{2}$. Uranium dioxide, both in nuclear fuel and uraninite, readily alters in the presence of water and oxygen resulting in the formation of uranyl-oxide hydroxy-hydrate minerals (UOH) (Finch \& Ewing, 1992; Wronkiewicz et al., 1992, 1996; Janeczek et al., 1996, and others). UOH minerals are among the first phases to form during the oxidation-hydration weathering of $\mathrm{UO}_{2}$ (Finch \& Ewing, 1992; Finch et al., 1996; Schindler \& Hawthorne, 2004; Krivovichev \& Plášil, 2013; Plášil, 2014). Because of their importance for nuclear waste disposal and the environmental chemistry of uranium in general (see e.g. O'Hare et al., 1988; Finch \& Murakami, 1999; Klingensmith et al., 2007; Kubatko et al. 2006; Maher et al., 2013), studies describing their structures and physical-chemical properties, such as solubility and thermodynamic stability, are numerous. Herein, we provide a description of the new mineral nollmotzite, which is the first naturally occurring uranium oxide that contains fluorine. It also is noteworthy for containing uranium as both $\mathrm{U}^{\mathrm{V}}$ and $\mathrm{U}^{\mathrm{VI}}$.

The name nollmotzite honors two German mineral collectors who discovered this new mineral; the name nollmotzite combines the first four letters of their surnames: Markus Noller (born 16.05.1977) and Reinhard Motzigemba (born 14.11.1952). Both the name and the new mineral were approved by the Commission on New Minerals, Nomenclature 
and Classification of the International Mineralogical Association (proposal IMA2017-100). The description is based on three cotype specimens deposited in the collections of the Natural History Museum of Los Angeles County, CA, USA, with catalog numbers 66647,66648 and 66649.

\section{Methodology}

\subsection{Sample}

Nollmotzite was found in June 2016 on the dump of the famous Clara mine in the Black Forest Mountains, BadenWürttemberg, Germany. Nollmotzite grows in cavities in quartz gangue with abundant dark-violet (nearly black) fluorite (so-called stinkspath) and barite. It forms thin prisms, elongated on [010], with chisel-like terminations (Figs. 1 and 2) up to about $0.3 \mathrm{~mm}$ in length. Crystals exhibit the forms (100), (100), (001), (001), (120) and (120). They are deep-violetbrown in color and are transparent with vitreous luster. Nollmotzite is non-fluorescent under longwave and shortwave ultraviolet radiation. Crystals are brittle, with a perfect cleavage on $\{001\}$. Examination by polarized light microscopy shows that nollmotzite is strongly pleochroic, $X=$ colorless, $Y=$ red-brown, $Z=$ deep violet $(X<<Y<Z)$. The optical orientation is $X \simeq \mathbf{c}^{*}, Y=\mathbf{b}, Z \simeq \mathbf{a}\left(X^{\wedge} \mathbf{c} \simeq 9^{\circ}\right.$ in obtuse $\left.\beta\right)$. Crystals are optically biaxial (-), with $\alpha=1.615$ (3), $\beta=$ $1.750(5), \gamma=1.765$ (5) (white light), $n_{\text {average }}=1.710,2 V_{\text {meas }}=$ $37(1)^{\circ}$ from extinction data analyzed using EXCALIBRW (Gunter et al., 2004), $2 V_{\text {calc }}=34.6^{\circ}$, dispersion is strong, $r>v$.

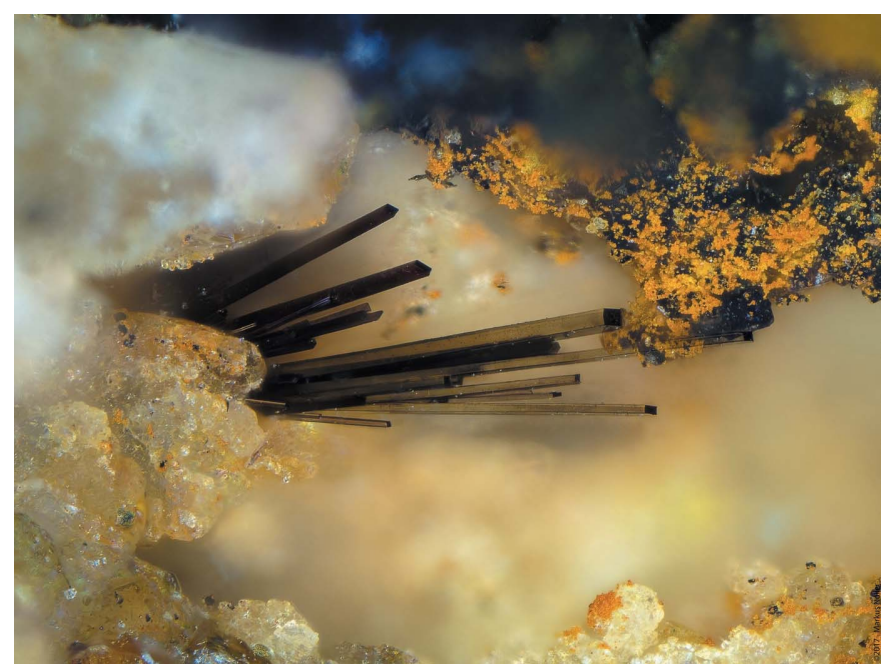

Figure 1

Nollmotzite crystals with typical chisel-like terminations in quartzfluorite gangue. Field of view $c a 1.2 \mathrm{~mm}$ across (photo by M. Noller).

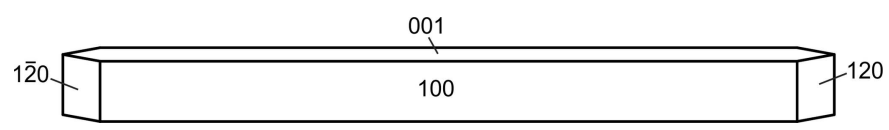

Figure 2

Crystal drawing of nollmotzite; clinographic projection in standard orientation.
Table 1

Chemical composition (in wt\%) of nollmotzite.

\begin{tabular}{llllll}
\hline & $\begin{array}{l}\text { Mean of } \\
\text { six spots } \\
\text { Constituent } \%)\end{array}$ & Range & $\begin{array}{l}\text { Standard } \\
\text { deviation }\end{array}$ & $\begin{array}{l}\text { Theoretical } \\
\text { composition } \dagger\end{array}$ & Standard \\
\hline $\mathrm{MgO}$ & 4.20 & $4.03-4.37$ & 0.13 & 4.05 & $\mathrm{Mg}_{2} \mathrm{SiO}_{4}$ \\
$\mathrm{CuO}$ & 0.12 & $0.05-0.35$ & 0.11 & & $\mathrm{Lammerite}$ \\
$\mathrm{UO}_{3}$ & $(84.18)$ & $83.28-85.28$ & 0.58 & $(86.20)$ & Parsonsite \\
$\mathrm{U}_{2} \mathrm{O}_{5} \ddagger$ & 27.28 & & & 27.93 & \\
$\mathrm{UO}_{3} \ddagger$ & 56.12 & & & 57.47 & \\
$\mathrm{~F}$ & 5.87 & $5.39-6.16$ & 0.25 & 5.72 & Topaz \\
$\mathrm{H}_{2} \mathrm{O} \S$ & 6.80 & & & 7.24 & \\
$-\mathrm{O}=\mathrm{F}$ & -2.47 & & & -2.41 & \\
Total & 97.92 & & & 100.00 & \\
\hline
\end{tabular}

$\dagger \mathrm{Mg}\left[\mathrm{U}^{\mathrm{V}}\left(\mathrm{U}^{\mathrm{VI}} \mathrm{O}_{2}\right)_{2} \mathrm{~F}_{3} \mathrm{O}_{4}\right]\left(\mathrm{H}_{2} \mathrm{O}\right)_{4}$. $\quad$ Apportioned in accord to the structure. $\S$ Based on structure.

\subsection{Electron microprobe}

The chemical composition of nollmotzite was determined using a Cameca SX100 electron microprobe (WDS mode, $15 \mathrm{kV}, 4 \mathrm{nA}, 5 \mu \mathrm{m}$ beam diameter). Because insufficient material was available for a direct determination of $\mathrm{H}_{2} \mathrm{O}$, it has been calculated by stoichiometry on the basis of three $\mathrm{U}$ and $15 \mathrm{O}+\mathrm{F}$ atoms per formula unit (apfu) in accord with the crystal structure determination. No other elements with atomic numbers higher than eight were observed. Analytical data are given in Table 1 . The empirical formula is $\left(\mathrm{Mg}_{1.06^{-}}\right.$ $\left.\mathrm{Cu}_{0.02}\right)_{\Sigma 1.08}\left[\mathrm{U}^{\mathrm{V}}\left(\mathrm{U}^{\mathrm{VI}} \mathrm{O}_{2}\right)_{2} \mathrm{O}_{3.85} \mathrm{~F}_{3.15}\right]\left[\left(\mathrm{H}_{2} \mathrm{O}\right)_{3.69}(\mathrm{OH})_{0.31}\right]_{\Sigma 4.00}$ (note that the $\mathrm{OH}$ is for charge balance and does not imply that some $\mathrm{H}_{2} \mathrm{O}$ sites are $\mathrm{OH}$ ).

\subsection{Raman spectroscopy}

Raman spectra of nollmotzite were recorded on a Horiba XploRA Plus spectrometer using a $532 \mathrm{~nm}$ diode laser. The spectra were recorded in two orientations: $\| \mathbf{c}^{*}$ (X optic direction), $\perp$ to the sheet of $\mathrm{U}$ polyhedra; and $\| \mathbf{a}$ (Z optic direction), $\|$ to the sheet of U polyhedra (Fig. 3).

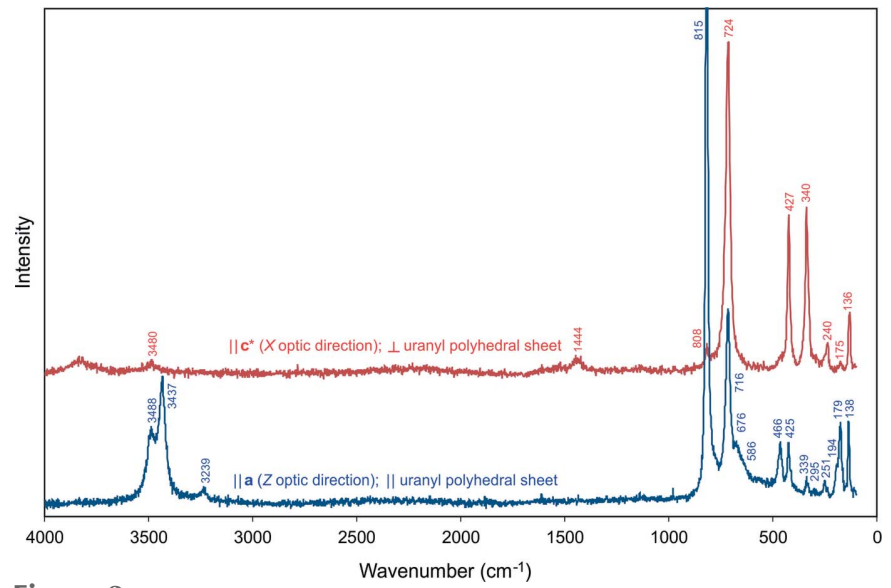

Figure 3

Raman spectra of nollmotzite collected with a $532 \mathrm{~nm}$ laser. 
Table 2

Data collection and refinement details for nollmotzite.

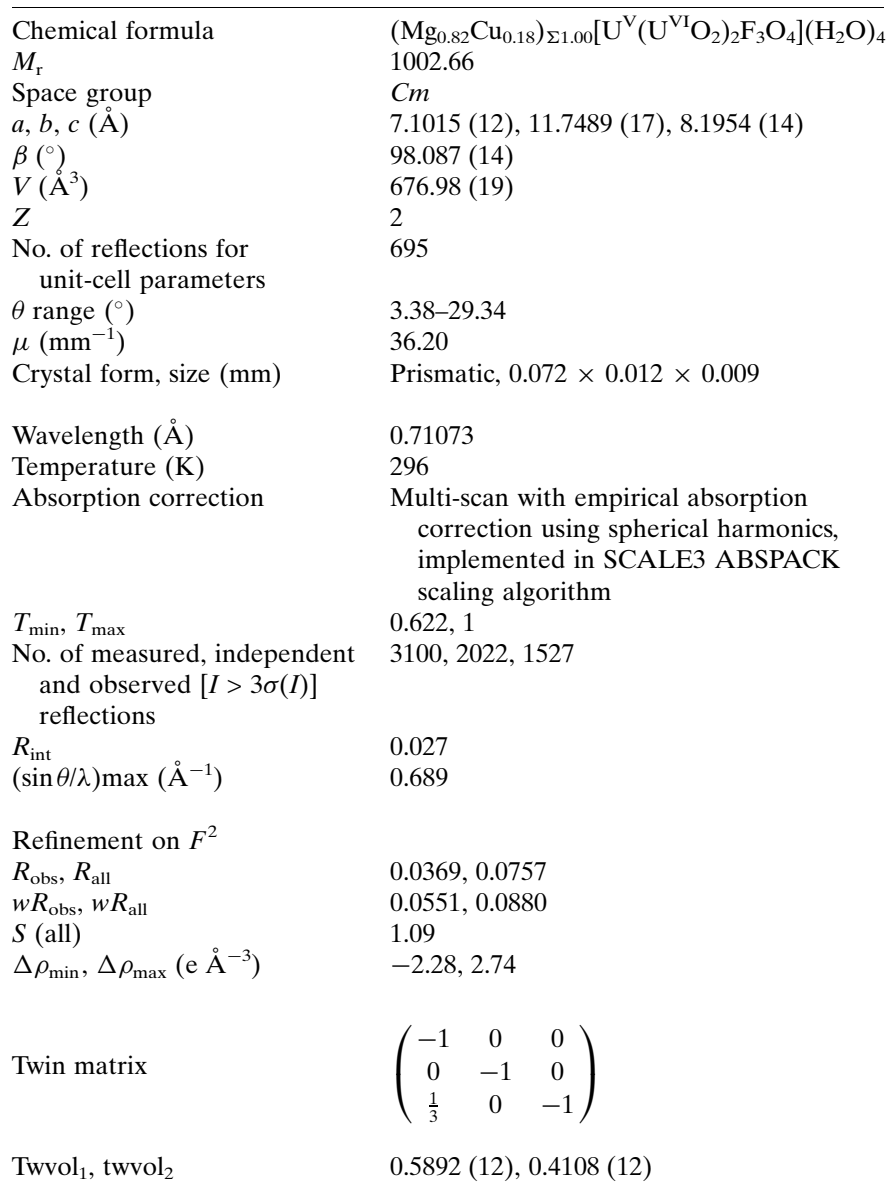

Computer programs: CrysAlis PRO v.1.171.38.43 (Rigaku Oxford Diffraction, 2017), JANA2006 (Petříček et al., 2014).

\subsection{X-ray diffraction}

2.4.1. Powder diffraction. X-ray powder diffraction data were recorded using a Rigaku R-Axis Rapid II curved imaging plate microdiffractometer with monochromated Mo $K \alpha$. A Gandolfi-like motion on the $\varphi$ and $\omega$ axes was used to randomize the sample. Observed $d$ values and intensities were derived by profile fitting using JADE 2010 (https://materialsdata.com/prodjd.html/) software. Data are given in the Table S1. Unit-cell parameters refined from the powder data using JADE 2010 with whole pattern fitting are as follows: $a=$

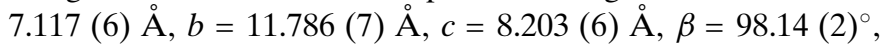
with $V=681.1(9) \AA^{3}$ and $Z=2$.

\subsection{Single-crystal diffraction}

For the single-crystal diffraction experiment, the crystal was selected under an polarized light microscope and mounted on a glass fiber. The diffraction experiment (see Table 2 for details) was performed at room temperature with a Rigaku SuperNova single-crystal diffractometer with an Atlas S2 $\mathrm{CCD}$ detector, using mirror monochromated Mo $K \alpha$ radiation from a microfocus X-ray tube. According to the single-crystal $\mathrm{X}$-ray experiment, nollmotzite is monoclinic, with space group
$\mathrm{Cm}$. Corrections for background, Lorentz, and polarization effects, as well as absorption correction were applied during data reduction in the CrysAlis (Rigaku Oxford Diffraction, 2017) package. Two datasets, representing two twin domains (characterized by distinct orientation matrix and related by the twin law) were produced by the data reduction (see \$2.6). The bond-valence sums were calculated following the procedure of Brown (2002), and utilizing bond-valence parameters taken from Burns et al. (1997a) and Gagné \& Hawthorne (2015).

\subsection{Structure solution and refinement of the twinned structure}

The structure of nollmotzite was solved from diffraction data using the charge-flipping algorithm of the program SHELXT (Sheldrick, 2015), and subsequently, it was refined using the Jana2006 (Petříček et al., 2014) program, based on $F^{2}$. The output from the SHELXT program suggested for monoclinic space group $\mathrm{Cm}$, which was later confirmed by the refinement. A quick test in Jana2006 revealed the possible presence of a twin by reticular (pseudo)merohedry (Petř́ícek et al., 2016), which can be indexed in the orthorhombic supercell. Careful inspection of diffraction frames and reconstruction of the reciprocal space of nollmotzite [UNWARP procedure in the CrysAlis (Rigaku Oxford Diffraction, 2017) software] confirmed the presence of diffractions of the second twin domain. The twin is by reflection on (100) leading to a complete overlap of reflections with $h+k=2 n$, and nonoverlapping reflections occur at a third of the real $\mathbf{c}^{*}$ parameter (Fig. 4). Taking the twinning into account, the refinement converged smoothly to more acceptable residuals $(R=$ $3.69 \%$ with $\mathrm{GoF}=1.09$ for 1527 unique observed reflections) (Table 2). During final cycles of the refinement, the $\mathrm{O} 2$ and $\mathrm{O} 6$ atoms were restricted to have the same atomic displacement parameters, because the $\mathrm{O} 2$ atom returned a low atomic displacement parameter value $\left(U_{\text {iso }}=0.003 \AA^{2}\right)$. We cannot exclude the possibility that this site is partially occupied by $\mathrm{F}$;
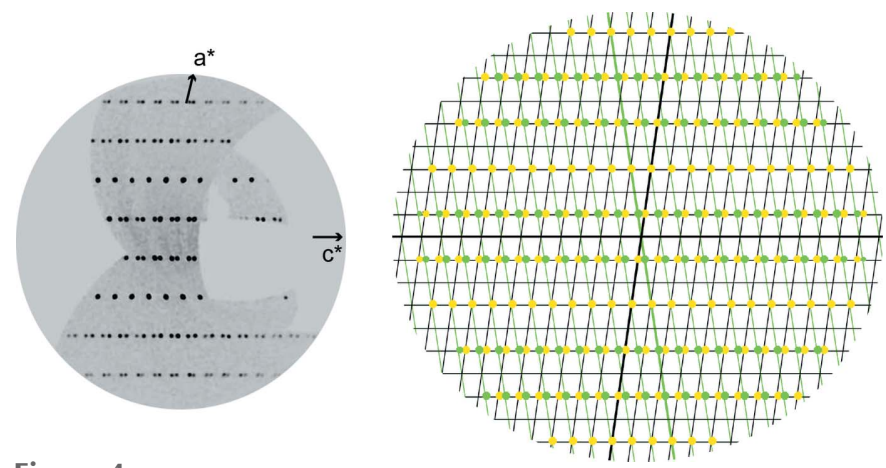

Figure 4

A twinned diffraction pattern of nollmotzite. A precession-like image (left) of reciprocal space, reconstructed with the UNWARP procedure of the CrysAlis software, $h 3 l$ plane and (right) the same diffraction pattern calculated using Jana2006 from the structure model determined here. Yellow spots belong to the first (larger) domain (with the corresponding lattice shown with black lines), while green spots belong to the second (weaker) twin domain (with the corresponding lattice drawn with the green lines). 
Table 3

Selected interatomic distances (in $\AA$ ) and measures of polyhedral distortion parameters for nollmotzite.

$\Phi$ and $\Phi_{\mathrm{eq}}$ denote ligands and equatorial ligands, respectively. $\mathrm{O}_{\mathrm{Ur}}$ denotes uranyl $\mathrm{O}$ atoms. ECoN is effective coordination number (Hoppe, 1979); octahedral distortion (Robinson et al., 1971); bond-angle variance $\left(\mathrm{deg}^{2}\right.$ ) (Robinson et al., 1971). Calculations of polyhedral distortion measured using VESTA (Momma \& Izumi, 2011) software.

\begin{tabular}{|c|c|c|c|c|c|}
\hline $\mathrm{U} 1-\mathrm{O} 2$ & $2.08(2)$ & $\mathrm{U} 2-\mathrm{O} 1$ & 1.807 (18) & $\mathrm{Mg} 1-\mathrm{F}^{\mathrm{iv}}$ & $1.92(4)$ \\
\hline $\mathrm{U} 1-\mathrm{O} 2^{\mathrm{i}}$ & $2.08(2)$ & $\mathrm{U} 2-\mathrm{O} 5$ & $1.77(2)$ & $\mathrm{Mg} 1-\mathrm{O} 3$ & $2.061(12)$ \\
\hline $\mathrm{U} 1-\mathrm{O} 6$ & $2.16(2)$ & $\mathrm{U} 2-\mathrm{O} 2$ & $2.34(2)$ & $\mathrm{Mg} 1-\mathrm{O}^{\mathrm{i}}$ & $2.061(12)$ \\
\hline $\mathrm{U} 1-\mathrm{O} 6^{\mathrm{i}}$ & $2.16(2)$ & $\mathrm{U} 2-\mathrm{O} 2^{\mathrm{ii}}$ & $2.36(2)$ & $\mathrm{Mg} 1-\mathrm{O} 4$ & $2.07(4)$ \\
\hline $\mathrm{U} 1-\mathrm{F} 2$ & $2.19(3)$ & $\mathrm{U} 2-\mathrm{O} 6^{\mathrm{ii}}$ & $2.31(2)$ & $\mathrm{Mg} 1-\mathrm{F} 3$ & $1.99(4)$ \\
\hline $\mathrm{U} 1-\mathrm{F} 3$ & $2.21(3)$ & $\mathrm{U} 2-\mathrm{O} 6^{\mathrm{iii}}$ & $2.30(2)$ & $\mathrm{Mg} 1-\mathrm{O} 7$ & $2.20(5)$ \\
\hline \multirow[t]{5}{*}{$\langle\mathrm{U} 1-\Phi\rangle$} & 2.15 & $\mathrm{U} 2-\mathrm{F} 1$ & $2.289(3)$ & $\langle\operatorname{Mg} 1-\Phi\rangle$ & 2.05 \\
\hline & & $\left\langle\mathrm{U} 2-\mathrm{O}_{\mathrm{Ur}}\right\rangle$ & 1.79 & $V_{\mathrm{Mg}}\left(\AA^{3}\right)$ & 11.41 \\
\hline & & $\left\langle\mathrm{U} 2-\Phi_{\mathrm{eq}}\right\rangle$ & 2.32 & ECoN & 5.53 \\
\hline & & & & Distortion & 0.031 \\
\hline & & & & $\begin{array}{c}\text { Bond-angle } \\
\text { variance }\end{array}$ & 14.06 \\
\hline
\end{tabular}

Symmetry codes: (i) $x,-y+1, z$; (ii) $x-\frac{1}{2},-y+\frac{3}{2}, z$; (iii) $x-1, y, z$; (iv) $x, y, z-1$.

however, a more probable explanation is that the low atomic displacement parameter is a relic resulting from an imperfect correction for the high absorption. Hydrogen atom positions were not determined due to the weak X-ray scattering factor of hydrogen and the predominance of uranium in the difference Fourier density maps. Final atom coordinates and displacement parameters are given in Tables S2 and S3, selected interatomic distances in Table 3 and bond-valence sums in Table 4.

\subsection{Voronoi-Dirichlet polyhedra calculations}

According to the stereoatomic model of crystals (e.g. Blatov et al., 1995, 1999), their structure is considered as being a partition of the three-dimensional space, where geometrical images of atoms are their Voronoi-Dirichlet polyhedra (VDP). For details of the application of VDP to the crystal chemistry of uranium, we refer to the paper by Serezhkin (2007). The number of faces, the form and volume $\left(V_{\mathrm{VDP}}\right)$ of the VDP are uniquely determined by the exact position of the atom in the particular structure. The linear parameters that characterize dimensions of a particular atom in the structure are the radius of the sphere, $R_{\mathrm{SD}}$ (in $\AA$ ) and its volume equal to $V_{\mathrm{VDP}}\left(\right.$ in $\left.\AA^{3}\right)$. Each face of VDP corresponds to a particular kind of interatomic interaction (i.e. bond). There are several parameters describing distortion of the atomic coordination in the VDP (Blatov et al., 1995; Blatov \& Serezhkin, 2000); among them, the second moment of inertia, $G_{3}$, describing the deviation of the VDP from an ideal sphere and characterizing the uniformity of distribution of the atoms around the centroid atom (here U). For an ideal sphere $G_{3}=0.077$, whereas for an ideal heteroatomic $A X_{6}$ octahedron (which corresponds to a cubic VD polyhedron), $G_{3}=0.0833$ (Blatov \& Serezhkin, 2000). The properties of Voronoi-Dirichlet polyhedra were calculated by the program Topos (Blatov et al., 2014).
Table 4

Bond-valence analysis (all values given in valence units, vu) of the crystal structure of nollmotzite.

The bond-valence parameters are taken from Brown \& Altermatt (1985) (for $\mathrm{Mg}-\mathrm{F}$ ), Brese \& O'Keeffe (1991) (for $\mathrm{Cu}-\mathrm{O}$ ), Burns et al. (1997a) (for U $\mathrm{U}^{\mathrm{VI}}-$ O), Gagné \& Hawthorne (2015) (for $\mathrm{Mg}-\mathrm{O}$ ) and Zachariasen (1978) (for $\mathrm{U}^{\mathrm{V}}-\mathrm{F}$ and $\mathrm{U}^{\mathrm{VI}}-\mathrm{F}$ ). Bond strengths of hydrogen bonds are taken from Hawthorne \& Schindler (2008) and correspond to an average $D-\mathrm{H}$ bond strength $(0.8 \mathrm{vu})$ and an average $\mathrm{H} \cdots A$ bond strength $(0.2 \mathrm{vu}) . \downarrow$ and $\rightarrow$ denote the direction in which multiplication should be applied.

\begin{tabular}{llllll}
\hline Atom & $\mathrm{U} 1$ & $\mathrm{U} 2$ & $\mathrm{Mg} 1 * / \mathrm{Cu} 1 *$ & $\Sigma \mathrm{BV}$ & Assignment \\
\hline O1 & & 1.59 & & 1.59 & $\mathrm{O}^{2-}(+2 \times 0.2 \mathrm{vu})$ \\
$\mathrm{O} 2$ & $0.99 \times 2 \downarrow$ & $0.56,0.54$ & & 2.09 & $\mathrm{O}^{2-}$ \\
O3 & & & 0.72 & 0.72 & $\mathrm{H}_{2} \mathrm{O}(+2 \times 0.8 \mathrm{vu})$ \\
O4 & & & 0.35 & 0.35 & $\mathrm{H}_{2} \mathrm{O}(+2 \times 0.8 \mathrm{vu})$ \\
O5 & & 1.71 & & 1.71 & $\mathrm{O}^{2-}(+2 \times 0.2 \mathrm{vu})$ \\
O6 & $0.86 \times 2 \downarrow$ & $0.59,0.61$ & & 2.06 & $\mathrm{O}^{2-}$ \\
O7 & & & 0.26 & 0.26 & $\mathrm{H}_{2} \mathrm{O}(+2 \times 0.8 \mathrm{vu})$ \\
F1 & & $0.46 \times 2 \rightarrow$ & & 0.92 & $\mathrm{~F}^{-}$ \\
F2 & 0.59 & & 0.41 & 1.00 & $\mathrm{~F}^{-}$ \\
F3 & 0.56 & & 0.34 & 0.90 & $\mathrm{~F}^{-}$ \\
IBV & 4.85 & 6.07 & 2.07 & & \\
\hline
\end{tabular}

\section{Results}

\subsection{Raman spectroscopy}

In the region of $\mathrm{O}-\mathrm{H}$ stretching vibrations, clear differences between two spectral orientations occur. In the spectrum $\| \mathbf{a}$, there is a pronounced two-component polarized band occurring at $3450 \mathrm{~cm}^{-1}$ (one at $\sim 3488 \mathrm{~cm}^{-1}$ and a stronger band at $3437 \mathrm{~cm}^{-1}$ ) and also an additional weak band at $3239 \mathrm{~cm}^{-1}$. These bands are related to the symmetric $\mathrm{O}-\mathrm{H}$ stretching vibrations of the water molecules bonded in the structure by hydrogen bonds of distinct strengths. The hydrogen bonds in the studied crystal correspond to $\mathrm{O} \cdots \mathrm{O}$ distances in the range from 2.81 (3) to 2.90 (4) $\AA$, fitting well with the correlation given by Libowitzky (1999). As expected, only a very weak band was observed at $\sim 3480 \mathrm{~cm}^{-1}$ in the spectrum $\| \mathbf{c}^{*}$. We assume it is due to the fact that there are fewer hydrogen bonds from the interlayer to the structure sheets; most of the hydrogen bonds are more or less parallel to the structural sheets. There is no band observed related to $\mathrm{H}-$ $\mathrm{O}-\mathrm{H}$ bending vibrations, which is not unusual for Raman spectroscopy. A weak band at $1444 \mathrm{~cm}^{-1}$, observed in the spectrum $\| \mathbf{c}^{*}$, may be assigned to an overtone or a combination band. A very strong band observed at $815 \mathrm{~cm}^{-1}$ in the spectrum $\| \mathbf{a}$ is attributed to the $v_{1}\left(\mathrm{UO}_{2}\right)^{2+}$ symmetric stretching vibration. According to Bartlett \& Cooney (1989), an approximate $\mathrm{U}-\mathrm{O}$ bond length of $1.8 \AA$ is in line with the bond length obtained from the structure $[c . f$. $\mathrm{U} 2-\mathrm{O}=1.77$ (2) and 1.81 (2) $\AA$ ]. These values are also in line with uranyl U$\mathrm{O}$ lengths in $\mathrm{UO}_{7}$ pentagonal bipyramids given by Lussier et al. (2016). A very weak band at $808 \mathrm{~cm}^{-1}$ in the spectrum $\| \mathbf{c}^{*}$ may be attributed to the same vibration as the symmetric stretching mode should be highly polarizable. A band of high intensity at $716 \mathrm{~cm}^{-1}$ in the spectrum $\| \mathbf{a}$, and at $724 \mathrm{~cm}^{-1}$ in the spectrum $\| \mathbf{c}^{*}$, is most probably connected with the $v_{1} \mathrm{U}-$ F symmetric stretching vibration. The shift towards the lower energy is due to the higher mass of $\mathrm{F}$ compared with that of $\mathrm{O}$. 
Shoulders at 676 and $586 \mathrm{~cm}^{-1}$ in the spectrum $\| \mathbf{a}$ are assigned to libration modes of molecular $\mathrm{H}_{2} \mathrm{O}$ (Lutz, 1988). Bands of medium intensity at 466 and $425 \mathrm{~cm}^{-1}$, plus the weak band at $339 \mathrm{~cm}^{-1}(\| \mathbf{a})$, and strong bands at 427 and $340 \mathrm{~cm}^{-1}\left(\| \mathbf{c}^{*}\right)$ are connected with the $v\left(\mathrm{U}-\mathrm{O}, \mathrm{F}_{\text {ligand }}\right)$ vibrations. Weak bands at $295 \mathrm{~cm}^{-1}$ and $251 \mathrm{~cm}^{-1}\left(\|\right.$ a) and a weak band at $240 \mathrm{~cm}^{-1}$ $\left(\| \mathbf{c}^{*}\right)$ are assigned to the $v_{2}(\delta)\left(\mathrm{UO}_{2}\right)^{2+}$ doubly degenerate bending vibrations. A band of medium intensity at $179 \mathrm{~cm}^{-1}$ ( $\|$ a) and a very weak band at $175 \mathrm{~cm}^{-1}\left(\| \mathbf{c}^{*}\right)$ may be assigned to the $\delta$ F-U-F bending vibrations; a shoulder- and a lowintensity band at 194 and $138 \mathrm{~cm}^{-1}$, respectively ( $\|$ a) and a weak band at $136 \mathrm{~cm}^{-1}\left(\| \mathbf{e}^{*}\right)$ are connected with translations and rotations of $\left(\mathrm{UO}_{2}\right)^{2+}$ (Dothée \& Camelot, 1982; Čejka et al., 1998).

\subsection{Crystal structure}

The structure of nollmotzite (Table S2) contains two U, one $\mathrm{Mg}$, three $\mathrm{F}$ and seven $\mathrm{O}$ sites (including three $\mathrm{O}$ sites of the molecular $\mathrm{H}_{2} \mathrm{O}$ ) (Fig. 5). The U1 site (Wyckoff notation $2 a$, site symmetry $m)$ is linked to six ligands, four $\mathrm{O}(\mathrm{O} 22 \times$; O6 $2 \times$ ) and two $F$ atoms (F2 and F3), while two $F$ atoms are positioned at vertices of the tetragonal $\mathrm{UF}_{2} \mathrm{O}_{4}$ bipyramid. The U2 site (Wyckoff notation $4 b$, site symmetry 1 ) is surrounded by seven ligands, including two axial uranyl $\mathrm{O}$ atoms (O1 and $\mathrm{O} 5)$ and five equatorial ligands (O2 2x; O6 2x; F1), forming a $\mathrm{UFO}_{6}$ pentagonal bipyramid (Fig. 6). The bond lengths of the $\mathrm{U} 1-\mathrm{F}$ bonds are 2.19 and $2.21 \AA$ (Table 3 ) and the bondvalence sums around the U1 site (Table 4) are consistent with this $\mathrm{U}$ being pentavalent. The uranyl pentagonal bipyramids share edges to form chains along [100] and chains of edgesharing squares (occupied by $\mathrm{UF}_{4} \mathrm{O}_{2}$ ) and triangles along the same direction (Fig. 7a); this results in the sheets stacked perpendicular to [001], which belong to the $\beta-\mathrm{U}_{3} \mathrm{O}_{8}$ topology (Fig. 7b) (Burns, 2005). The Mg1 site is octahedrally coordinated by two mutually trans F atoms (belonging to the U1 site)

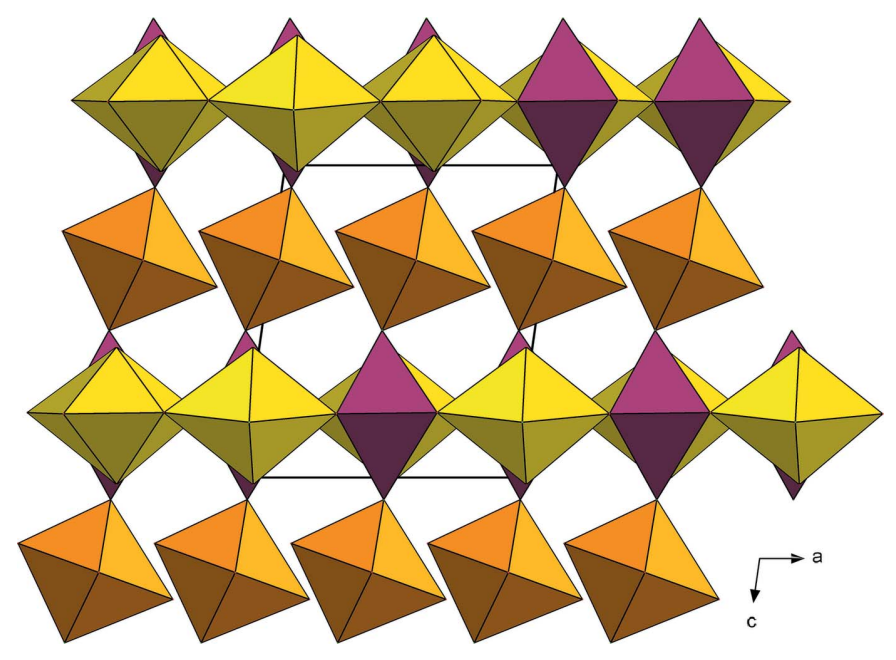

Figure 5

Crystal structure of nollmotzite viewed along b. The sheets of $U$ polyhedra (yellow and violet) alternate interlayer with $\mathrm{Mg}\left(\mathrm{H}_{2} \mathrm{O}\right)_{4}$ octahedra (orange). and four $\mathrm{O}$ atoms in equatorial configuration (two $\mathrm{O} 3$ atoms related by symmetry, $\mathrm{O} 4$ and $\mathrm{O} 7$ atoms) that are $\mathrm{H}_{2} \mathrm{O}$ molecules. According to the results of the electron microprobe analyses, nollmotzite contains minor $\mathrm{Cu}$ along with dominant $\mathrm{Mg}$. A partial substitution of $\mathrm{Cu}$ at the $\mathrm{Mg}$ site was documented by the site-scattering refinement; however, because of the small amount of $\mathrm{Cu}^{2+}$ entering the site (less than 0.2 atoms per unit cell), no distortion of the octahedral coordination due to the Jahn-Teller effect was observed (see polyhedral distortion parameters for the Mg polyhedron; Table 3). Adjacent sheets of $\mathrm{U}$ polyhedra are linked through the $\mathrm{F}-$ $\mathrm{Mg}-\mathrm{F}$ linkages, as well as through hydrogen bonds. The arrangement of the hydrogen bonds network can be deduced based on the bond-valence analysis (Table 4). Within the structural sheets the only acceptors of the hydrogen bonds, which emanate from the $\mathrm{H}_{2} \mathrm{O}$ groups $(\mathrm{O} 3, \mathrm{O}$, O4, O7 coordinated to $\mathrm{Mg} 1 / \mathrm{Cu} 1$ atom) in interlayer, are uranyl oxygen atoms (O1 and $\mathrm{O} 5)$ linked to the $\mathrm{U} 2$ atom. The $\mathrm{O} \cdots \mathrm{O}$ distances related to hydrogen-bond interactions are 2.81 (3) $\AA$

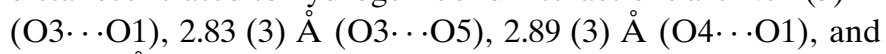
2.90 (4) $\AA$ (O7...O5). The respective angles (acceptordonor-acceptor), $\mathrm{O} 1-\mathrm{O} 4-\mathrm{O} 1 \quad\left(101.8^{\circ}\right), \quad \mathrm{O} 5-\mathrm{O} 7-\mathrm{O} 5$

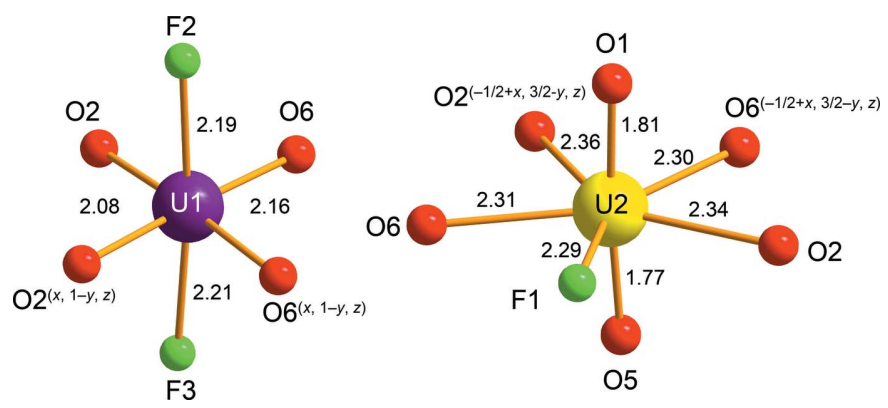

Figure 6

Coordination of $\mathrm{U}$ atoms in the structure of nollmotzite; violet $\mathrm{U} 1$ is $\mathrm{U}^{\mathrm{V}}$ and yellow $\mathrm{U} 2$ is $\mathrm{U}^{\mathrm{VI}}$. Bond lengths are given in $\AA$. (a)

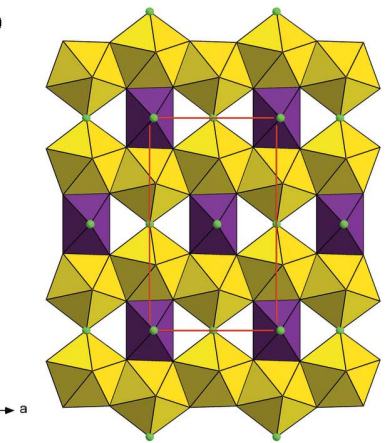

(b)

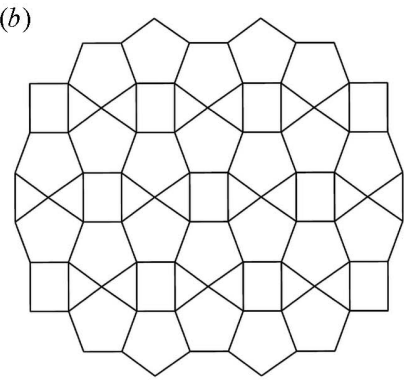

Figure 7

(a) The $\left[\mathrm{U}^{\mathrm{V}}\left(\mathrm{U}^{\mathrm{VI}} \mathrm{O}_{2}\right)_{2} \mathrm{O}_{4} \mathrm{~F}_{3}\right]^{2-}$ sheet in the structure of nollmotzite. The $\mathrm{F}$ sites are displayed in green, $\mathrm{U}^{\mathrm{V}}$ polyhedra (U1) are in violet, $\mathrm{U}^{\mathrm{VI}}$ polyhedra (U2) are in yellow; unit-cell edges outlined with a solid red line. (b) Its respective topology $\left(\beta-\mathrm{U}_{3} \mathrm{O}_{8}\right.$ type $)$. 
Table 5

Voronoi-Dirichlet polyhedra parameters for $\mathrm{U}$ atoms in the selected structures.

\begin{tabular}{|c|c|c|c|c|c|c|}
\hline Structure; \#atom & $\mathrm{U}^{n}$ & $\mathrm{CN}$ & $\begin{array}{l}V_{\mathrm{VDP}} \\
\left(\AA^{3}\right) \\
\end{array}$ & $\begin{array}{l}R_{\mathrm{SD}} \\
(\AA)\end{array}$ & $G_{3}$ & Ref. \\
\hline Nollmotzite; U1 & 5 & 6 & 10.1800 & 1.3450 & 0.0852 & (a) \\
\hline Nollmotzite; U2 & 6 & 7 & 8.7700 & 1.2790 & 0.0833 & \\
\hline Richetite; U4 & 6 & 7 & 9.2600 & 1.3030 & 0.0855 & \\
\hline Wyartite; U1 & 6 & 7 & 9.2300 & 1.3010 & 0.0832 & (c) \\
\hline Wyartite; U2 & 6 & 7 & 8.8600 & 1.2840 & 0.0835 & \\
\hline Shinkolobweite; U1 & 6 & 7 & 8.9700 & 1.2890 & 0.0836 & (e) \\
\hline Shinkolobweite; U2 & 5 & 6 & 9.6700 & 1.3220 & 0.0889 & \\
\hline Ianthinite; U4 & 4 & 6 & 9.9500 & 1.3340 & 0.0851 & $(f)$ \\
\hline$\left[\mathrm{U}^{\mathrm{V}}\left(\mathrm{H}_{2} \mathrm{O}\right)_{2}\left(\mathrm{U}^{\mathrm{VI}} \mathrm{O}_{2}\right)_{2} \mathrm{O}_{4}(\mathrm{OH})\right]\left(\mathrm{H}_{2} \mathrm{O}\right)_{4} ; \mathrm{U} 1$ & 5 & 6 & 10.5500 & 1.3610 & 0.0857 & $(g)$ \\
\hline $\mathrm{K}_{13}\left[\left(\mathrm{UO}_{2}\right)_{19}\left(\mathrm{UO}_{4}\right)\left(\mathrm{B}_{2} \mathrm{O}_{5}\right)_{2}\left(\mathrm{BO}_{3}\right)_{6}(\mathrm{OH})_{2} \mathrm{O}_{5}\right]\left(\mathrm{H}_{2} \mathrm{O}\right) ; \mathrm{U} 6$ & 6 & 7 & 9.0700 & 1.2940 & 0.0836 & $(h)$ \\
\hline $\mathrm{K}_{13}\left[\left(\mathrm{UO}_{2}\right)_{19}\left(\mathrm{UO}_{4}\right)\left(\mathrm{B}_{2} \mathrm{O}_{5}\right)_{2}\left(\mathrm{BO}_{3}\right)_{6}(\mathrm{OH})_{2} \mathrm{O}_{5}\right]\left(\mathrm{H}_{2} \mathrm{O}\right) ; \mathrm{U} 10$ & 5 & 6 & 9.6200 & 1.3190 & 0.0872 & \\
\hline $\mathrm{Cs}_{8} \mathrm{U}^{\mathrm{IV}}\left(\mathrm{U}^{\mathrm{VI}} \mathrm{O}_{2}\right)_{3}\left(\mathrm{Ge}_{3} \mathrm{O}_{9}\right)_{3}\left(\mathrm{H}_{2} \mathrm{O}\right)_{3} ; \mathrm{U} 1$ & 4 & 6 & 10.7500 & 1.3690 & 0.0833 & (i) \\
\hline $\mathrm{U}_{2} \mathrm{MoO}_{8} ; \mathrm{U} 2$ & 5 & 7 & 10.1400 & 1.3430 & 0.08340 & \\
\hline $\mathrm{UTa}_{3} \mathrm{O}_{10} ; \mathrm{U} 1$ & 5 & 8 & 10.4900 & 1.3580 & 0.08316 & $(m)$ \\
\hline $\mathrm{UVO}_{5} ; \mathrm{U} 1$ & 5 & 7 & 9.6700 & 1.3220 & 0.08201 & (n) \\
\hline $\mathrm{U}_{5} \mathrm{O}_{12} \mathrm{Cl} ; \mathrm{U} 1$ & 5 & 6 & 10.5500 & 1.361 & 0.08498 & $(o)$ \\
\hline $\mathrm{U}_{5} \mathrm{O}_{12} \mathrm{Cl} ; \mathrm{U} 2$ & 5 & 7 & 10.1100 & 1.341 & 0.08275 & \\
\hline $\mathrm{U}_{5} \mathrm{O}_{12} \mathrm{Cl} ; \mathrm{U} 3$ & 5 & 7 & 10.1100 & 1.341 & 0.08212 & \\
\hline
\end{tabular}

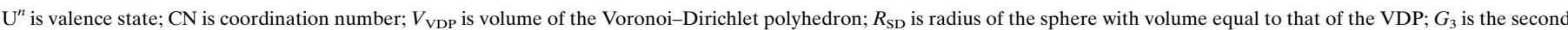

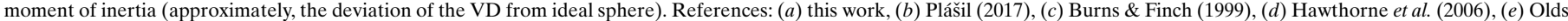

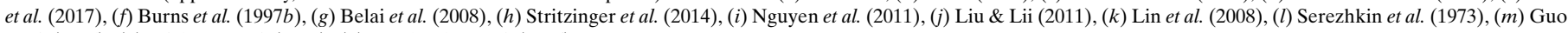
et al. (2016), (n) Dickens et al. (1992), (o) Cordfunke et al. (1985).

$\left(102.4^{\circ}\right)$ and $\mathrm{O} 1-\mathrm{O} 3-\mathrm{O} 5\left(112.2^{\circ}\right)$, are similar to the theoretical $\mathrm{H}-\mathrm{O}-\mathrm{H}$ angle $\left(104.5^{\circ}\right)$ in an $\mathrm{H}_{2} \mathrm{O}$ molecule.

The structural formula of nollmotzite obtained from the refinement and bond-valence considerations is $\left\{{ }^{[6]} \mathrm{Mg}\left(\mathrm{H}_{2}{ }^{[3]} \mathrm{O}\right)_{4}\right\}^{2+}\left[\mathrm{U}^{\mathrm{V}}\left(\mathrm{U}^{\mathrm{VI}} \mathrm{O}_{2}\right)_{2} \mathrm{~F}_{3} \mathrm{O}_{4}\right]^{2-}, Z=2$.

\section{Discussion}

4.1. Nollmotzite and related minerals and compounds containing $\mathrm{U}^{\mathrm{V}}$

Nollmotzite, $\mathrm{Mg}\left[\mathrm{U}^{\mathrm{V}}\left(\mathrm{U}^{\mathrm{VI}} \mathrm{O}_{2}\right)_{2} \mathrm{~F}_{3} \mathrm{O}_{4}\right]\left(\mathrm{H}_{2} \mathrm{O}\right)_{4}$, is the fourth mineral known to contain pentavalent uranium, the others being wyartite, $\mathrm{Ca}\left(\mathrm{CO}_{3}\right)\left[\mathrm{U}^{\mathrm{V}}\left(\mathrm{U}^{\mathrm{VI}} \mathrm{O}_{2}\right)_{2} \mathrm{O}_{4}(\mathrm{OH})\right]\left(\mathrm{H}_{2} \mathrm{O}\right)_{7}$ (Burns \& Finch, 1999), shinkolobweite, $\mathrm{Pb}_{1.25}\left[\mathrm{U}^{\mathrm{V}}\left(\mathrm{H}_{2} \mathrm{O}\right)_{2^{-}}\right.$ $\left.\left(\mathrm{U}^{\mathrm{VI}} \mathrm{O}_{2}\right)_{5} \mathrm{O}_{8}(\mathrm{OH})_{2}\right]\left(\mathrm{H}_{2} \mathrm{O}\right)_{5}$ (Olds et al., 2017), and richetite, $\mathrm{Fe}_{0.5} \mathrm{~Pb}_{5}\left[\mathrm{U}^{\mathrm{V}}\left(\mathrm{U}^{\mathrm{VI}} \mathrm{O}_{2}\right)_{17} \mathrm{O}_{18}(\mathrm{OH})_{14}\right]\left(\mathrm{H}_{2} \mathrm{O}\right)_{\sim 19.5}$ (Plášil, 2017). Dehydrated wyartite, $\mathrm{Ca}\left(\mathrm{CO}_{3}\right)\left[\mathrm{U}^{\mathrm{V}}\left(\mathrm{U}^{\mathrm{VI}} \mathrm{O}_{2}\right)_{2} \mathrm{O}_{4}(\mathrm{OH})\right]\left(\mathrm{H}_{2} \mathrm{O}\right)_{3}$ (Hawthorne et al., 2006), which also contains $\mathrm{U}^{\mathrm{V}}$, is not approved officially as a mineral by the International Mineralogical Association. While nollmotzite, both hydrated and dehydrated wyartite, and shinkolobweite contain structural sheets based on $\beta-\mathrm{U}_{3} \mathrm{O}_{8}$ topology, richetite possesses sheets of $\alpha-\mathrm{U}_{3} \mathrm{O}_{8}$ topology (the fourmarierite type). The family of synthetic compounds that contains $\mathrm{U}^{\mathrm{V}}$ is broader. Among them, the most similar to the aforementioned mineral structures is that of synthetic $\left[\mathrm{U}^{\mathrm{V}}\left(\mathrm{H}_{2} \mathrm{O}\right)_{2}\left(\mathrm{U}^{\mathrm{VI}} \mathrm{O}_{2}\right)_{2} \mathrm{O}_{4}(\mathrm{OH})\right]\left(\mathrm{H}_{2} \mathrm{O}\right)_{4}$ (Belai et al., 2008), whose structure is also based upon sheets of $\beta-\mathrm{U}_{3} \mathrm{O}_{8}$ topology.
The incorporation of fluorine into uranyl oxide sheet structures has not been previously observed, but the nollmotzite structure demonstrates that it is possible. Both $\alpha$ $\mathrm{U}_{3} \mathrm{O}_{8}$ and $\beta-\mathrm{U}_{3} \mathrm{O}_{8}$ topologies have the same $\mathrm{U}: \mathrm{O}$ ratio (3:5), and also similar U:OH content (Krivovichev, 2013; Plášil, 2018). We can expect that the incorporation of fluorine is of equal probability for both topological types.

Recently, two synthetic phases, uranyl oxides that contain fluorine, have been synthesized. The structure of synthetic phase $\left[\left(\mathrm{UO}_{2}\right)_{4} \mathrm{~F}_{13}\right]\left[\mathrm{Sr}_{3}\left(\mathrm{H}_{2} \mathrm{O}\right)_{8}\right]\left(\mathrm{NO}_{3}\right) \cdot \mathrm{H}_{2} \mathrm{O}$ (Jouffret et al., 2016) is based upon sheets, where fluorine acts as a ligand of pentagonal bipyramids coordinating $\mathrm{U}^{\mathrm{VI}}$. Felder et al. (2018) synthesized a mixed $\mathrm{Co}^{\mathrm{II}}$-uranyl-oxide-fluoride hexahydrate, $\left[\mathrm{Co}\left(\mathrm{H}_{2} \mathrm{O}\right)_{6}\right]_{3}\left[\mathrm{U}_{2} \mathrm{O}_{4} \mathrm{~F}_{7}\right]_{2}$. Nevertheless, this synthetic phase contains only hexavalent U. Thus, fluorine acts as an equatorial ligand of $\mathrm{UO}_{2}{ }^{2+}$. The structure is based upon infinite chains of $\left[\mathrm{U}_{2} \mathrm{O}_{4} \mathrm{~F}_{7}\right]$ dimer units.

4.2. Remarks on the coordination of $U^{\mathrm{V}}$ and $U^{\mathrm{VI}}$ in the solid state

The $\mathrm{U}^{\mathrm{VI}}$, present as the uranyl ion $\mathrm{UO}_{2}{ }^{2+}\left(\mathrm{UrO}_{2}\right)$, occurs most typically in three types of coordination polyhedra: (1) square bipyramids ( $\mathrm{UrO}_{2} \Phi_{4}$; four equatorial ligands), (2) pentagonal bipyramids ( $\mathrm{UrO}_{2} \Phi_{5}$; five equatorial ligands), and (3) hexagonal bipyramids ( $\mathrm{UrO}_{2} \Phi_{6}$; six equatorial ligands). A bimodal distribution of bond lengths is observed for uranyl pentagonal and hexagonal bipyramids. For both, the $\mathrm{U}-\mathrm{O}_{\mathrm{yl}}$ bond lengths in the uranyl ion are significantly shorter than 
the $\mathrm{U}-\mathrm{O}_{\text {eq }}$ bonds (Burns et al., 1997a; Lussier et al., 2016; following values are based upon 222 well refined structures). The average ${ }^{[7]} \mathrm{U}^{6+}-\mathrm{O}_{\mathrm{yl}}$ is $1.793 \AA(\sigma=0.035 \AA) ;{ }^{[7]} \mathrm{U}^{6+}-\mathrm{O}_{\text {eq }}$ is $2.368 \AA(\sigma=0.100 \AA)$. The average ${ }^{[8]} \mathrm{U}^{6+}-\mathrm{O}_{\mathrm{yl}}$ bond is 1.783 $(\sigma=0.030 \AA)$; the average $\mathrm{U}^{6+}-\mathrm{O}_{\text {eq }}$ bond is $2.460 \AA(\sigma=$ $0.107 \AA)$. In the case of ${ }^{[6]} \mathrm{U}^{6+}$, the uranyl cation is coordinated by four equatorial ligands with an average $\mathrm{U}-\mathrm{O}_{\mathrm{yl}}$ bond of $1.816 \AA(\sigma=0.050 \AA)$ and an average $\mathrm{U}-\mathrm{O}_{\mathrm{eq}}$ bond of $2.264(\sigma$ $=0.064 \AA$ ). Nevertheless, there are also examples of structures containing $\mathrm{U}^{6+}$ in a regular (or distorted) octahedral coordination, where the average $\mathrm{U}-\mathrm{O}$ bond lengths are $\sim 2.1 \AA$ (e.g. Morrison et al., 2011). Furthermore, in at least two reported structures (Wu et al., 2009; Unruh et al., 2010), ${ }^{[6]} \mathrm{U}^{6+}$ adopts an unusual tetraoxido core, wherein the four equatorial bonds of the octahedra are short, $\sim 1.8 \AA$, and the axial bonds are longer, $\sim 2.3 \AA$.

In contrast to $\mathrm{U}^{\mathrm{VI}}$ compounds, there are only a few well defined $U^{\mathrm{V}}$ structures known. Among the oxo-compounds, the most common coordination number of $\mathrm{U}^{\mathrm{V}}$ is [7] (Table S4); there are 56 individual values with an average $\mathrm{U}^{\mathrm{V}}-\mathrm{O}$ bond length of $2.25 \AA(\sigma=0.03 \AA)$ (with the median at $2.20 \AA$ ); the distribution of bond lengths (Fig. S1) shows a positive skewness (1.335).

To probe the character of bonding interactions within the $\mathrm{U}^{\mathrm{V}}-\Phi$ polyhedra, an analysis using Voronoi-Dirichlet polyhedra (VDP) was carried out, the results of which are given in Table 5. The values of the second momentum of inertia, $G_{3}$, which characterizes the sphericity of VDP, ranges from 0.082 to 0.089 . The $G_{3}$ value of 0.082 is taken as the threshold indicating covalent bonding character (Blatov \& Serezhkin, 2000). An interesting feature that distinguishes $U^{V}$ from $U^{V I}$ is

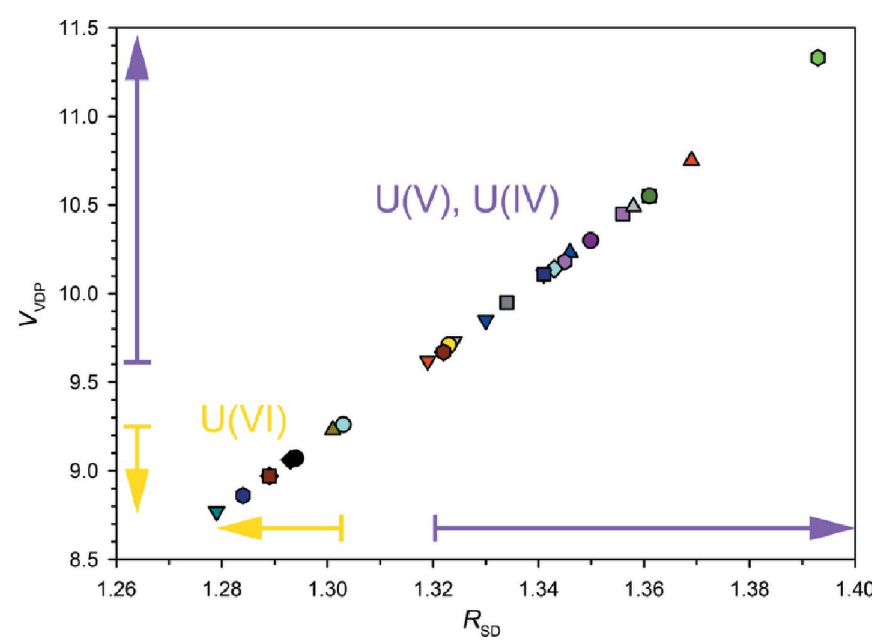

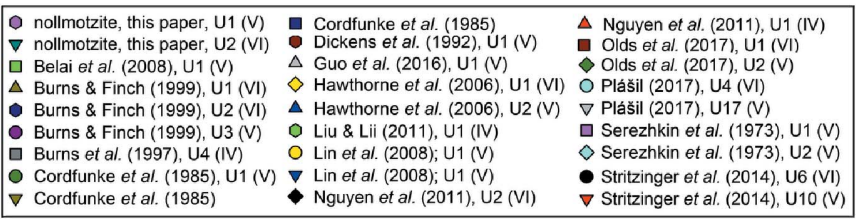

\section{Figure 8}

A plot of Voroni-Dirichlet polyhedra (VDP) measures: equivalent radius of the sphere $\left(R_{\mathrm{SD}}\right.$, in $\AA$ ) and a volume of $\operatorname{VDP}\left(V_{\mathrm{VDP}}\right.$, in $\left.\AA^{3}\right)$ displaying characteristic values for $\mathrm{U}^{\mathrm{VI}}, \mathrm{U}^{\mathrm{V}}$ and $\mathrm{U}^{\mathrm{IV}} \mathrm{VDP}$ as well. the volume of corresponding VDP, and consequently also the equivalent radius, $R_{\mathrm{SD}}$. The relationship displayed in Fig. 8, showing a linear trend, allows $\mathrm{U}^{\mathrm{V}}$ (higher VDP) to be distinguished from $\mathrm{U}^{\mathrm{VI}}$ (lower VDP). The lowest VDP volume observed for $\mathrm{U}^{\mathrm{V}}$ is $9.62 \AA^{3}$ (with equivalent radius, $R_{\mathrm{SD}}$, of $1.32 \AA$ ), while the largest VDP volume observed for $\mathrm{U}^{\mathrm{VI}}$ is $9.26 \AA^{3}$ (with $R_{\mathrm{SD}}=1.30 \AA$ ).

\section{Implications}

The formation of nollmotzite is a result of solid-state precipitation from U-containing aqueous solutions under partially reducing conditions. Nollmotzite contains $\sim 20 \mathrm{~mol} . \% \mathrm{~F}$ in a structural unit, suggesting that the fugacity of $\mathrm{O}_{2}$ was lower than under fully oxidizing conditions. The reducing environment was most probably enhanced by consumption of oxygen during the oxidation of abundant pyrite present in the gangue (crusts of $\mathrm{Fe}^{\mathrm{III}}$ oxyhydroxides are abundant on the samples). The major gangue minerals are dark varieties of fluorite (called stinkspath or antozonite), barite and quartz. The high fugacity of fluorine and low fugacity of oxygen led to the incorporation of fluorine into the sheet structure of nollmotzite and a partial reduction of $\mathrm{U}^{\mathrm{VI}}$ to $\mathrm{U}^{\mathrm{V}}$. The discovery of nollmotzite contributes to the large body of radioactive-waste final-disposal research. In designing final repositories for radioactive waste, the paradigm has shifted from using oxidative conditions towards using strongly reducing conditions (Ewing, 2015; Ewing et al., 2016; Rojo et al., 2018). Reducing environments are considered preferable to prevent the corrosion of the stainless steel tanks embedded in clay/ cement after the closure of the repository. In spite of efforts to create overall reducing conditions, oxygen atoms will continue to be available from groundwater and/or dissolved oxygencontaining minerals in the backfill. Stainless steel used for the fabrication of tanks in the repository generally does not contain fluorine (even if there are some industrial passivation processes based on fluorination). However, traces of fluorine can be derived from dissolution of phosphate minerals present in the backfill, or it can be present in the groundwater. The corrosion processes take place at the interfaces between radioactive waste and tanks/backfill/surrounding rocks, and they are often bounded onto small (micro) areas with strong geochemical gradients.

\section{Conclusions}

The new mineral found at the Clara mine, Black Forest Mountains, Germany, is the first known naturally occurring uranium oxide that contains significant fluorine. Furthermore, the reducing conditions under which this mineral formed led to the partial reduction of the $\mathrm{U}^{\mathrm{VI}}$ to $\mathrm{U}^{\mathrm{V}}$. Therefore, nollmotzite is one of the very few minerals containing pentavalent uranium. The characterization of new supergene uranium minerals with unusual structural and/or compositional features, such as nollmotzite, can provide valuable insights into processes that may occur during the long-term storage of spent nuclear fuel. 


\section{Funding information}

The following funding is acknowledged: this research was supported by the project No. LO1603 under the Ministry of Education, Youth and Sports National sustainability program I of the Czech Republic (grant No. LO1603 to Institute of Physics ASCR, v.v.i.) and by the Ministry of Culture of the Czech Republic (DKRVO 2108/02; National Museum 00023272) to JČ (grant No. DKRVO 2108/02 to National Museum in Prague).

\section{References}

Bartlett, J. R. \& Cooney, R. P. (1989). J. Mol. Struct. 193, 295-300.

Belai, N., Frisch, M., Ilton, E. S., Ravel, B. \& Cahill, C. L. (2008). Inorg. Chem. 47, 10135-10140.

Blatov, V. A. \& Serezhkin, V. N. (2000). Russ. J. Inorg. Chem. 45, S105-S222.

Blatov, V. A., Shevchenko, A. P. \& Proserpio, D. M. (2014). Cryst. Growth Des. 14, 3576-3586.

Blatov, V. A., Shevchenko, A. P. \& Serenzhkin, V. N. (1995). Acta Cryst. A51, 909-916.

Blatov, V. A., Shevchenko, A. P. \& Serezhkin, V. N. (1999). Koord. Khim. 25, 483-497.

Brese, N. E. \& O'Keeffe, M. (1991). Acta Cryst. B47, 192-197.

Brown, I. D. (2002). The Chemical Bond in Inorganic Chemistry: The Bond Valence Model, pp. 278. Oxford University Press.

Brown, I. D. \& Altermatt, D. (1985). Acta Cryst. B41, 244-247.

Burns, P. C. (2005). Can. Mineral. 43, 1839-1894.

Burns, P. C., Ewing, R. C. \& Hawthorne, F. C. (1997a). Can. Mineral. 35, 1551-1570.

Burns, P. C. \& Finch, R. J. (1999). Am. Mineral. 84, 1456-1460.

Burns, P. C., Finch, R. J., Hawthorne, F. C., Miller, M. L. \& Ewing, R. C. (1997b). J. Nucl. Mater. 249, 199-206.

Čejka, J., Sejkora, J., Skála, R., Čejka, J. Jr, Novotná, M. \& Ederová, J. (1998). N. Jahrb. Miner. Abh. 174, 159-180.

Cordfunke, E. H. P., van Vlaanderen, P. V., Goubitz, K. \& Loopstra, B. O. (1985). J. Solid State Chem. 56, 166-170.

Dickens, P. G., Stuttard, G. P., Ball, R. G. J., Powell, A. V., Hull, S. \& Patat, S. (1992). J. Mater. Chem. 2, 161-166.

Dothée, D. G. \& Camelot, M. M. (1982). Bull. Soc. Chim. Fr. 3-4, 97102.

Ewing, R. C. (2015). Nat. Mater. 14, 252-257.

Ewing, R. C., Whittleston, R. A. \& Yardley, B. W. D. (2016). Elements, 12, 233-237.

Felder, J. B., Smith, M. \& zur Loye, H.-C. (2018). Cryst. Growth Des. 18, 1236-1244.

Finch, R. J. \& Ewing, R. C. (1992). J. Nucl. Mater. 190, 133-156.

Finch, R. J. \& Murakami, T. (1999). Rev. Mineral. Geochem. 38, 91179.

Finch, R. J., Suksi, J., Rasilainen, K. \& Ewing, R. C. (1996). Mater. Res. Soc. Symp. Proc. 412, 823-830.

Gagné, O. C. \& Hawthorne, F. C. (2015). Acta Cryst. B71, 562-578.

Gunter, M. E., Bandli, B. R., Bloss, F. D., Evans, S. H., Su, S. C. \& Weaver, R. (2004). Microscope, 52, 23-39.

Guo, X., Lipp, C., Tiferet, E., Lanzirotti, A., Newville, M., Engelhard, M. H., Wu, D., Ilton, E. S., Sutton, S. R., Xu, H., Burns, P. C. \& Navrotsky, A. (2016). Dalton Trans. 45, 18892-18899.

Hawthorne, F. C., Finch, R. J. \& Ewing, R. C. (2006). Can. Mineral. 44, 1379-1385.

Hawthorne, F. C. \& Schindler, M. (2008). Z. Kristallogr. 223, 41-68.

Hoppe, R. (1979). Z. Kristallogr. 150, 23-52.

Janeczek, J., Ewing, R. C., Oversby, V. M. \& Werme, L. O. (1996). J. Nucl. Mater. 238, 121-130.
Jouffret, L. J., Hiltbrunner, J.-M., Rivenet, M., Sergent, N., Obbade, S., Avignant, D. \& Dubois, M. (2016). Inorg. Chem. 55, 12185 12192.

Klingensmith, A. L., Deely, K. M., Kinman, W. S., Kelly, V. \& Burns, P. C. (2007). Am. Mineral. 92, 662-669.

Krivovichev, S. V. (2013). Crystal Chemistry of Uranium Oxides and Minerals. Comprehensive Inorganic Chemistry II, pp. 611-640. Elsevier.

Krivovichev, S. V. \& Plášil, J. (2013). In Uranium, from Cradle to Grave, edited by P. C. Burns and G. E. Sigmon. MAC Short Course series, Vol. 43, pp. 15-119. Mineralogical Association of Canada.

Kubatko, K. A., Helean, K., Navrotsky, A. \& Burns, P. C. (2006). Am. Mineral. 91, 658-666.

Libowitzky, E. (1999). Monatsh. Chem. 130, 1047-1059.

Lin, Ch.-H., Chen, Ch.-S., Shiryaev, A. A., Zubavichus, Ya. V. \& Lii, K.-H. (2008). Inorg. Chem. 47, 4445-4447.

Liu, H.-K. \& Lii, K.-H. (2011). Inorg. Chem. 50, 5870-5872.

Lussier, A. J., Lopez, R. A. K. \& Burns, P. C. (2016). Can. Mineral. 54, $177-283$.

Lutz, H. D. (1988). Struct. Bond. 69, 99-125.

Maher, K., Bargar, J. R. \& Brown, G. E. Jr (2013). Inorg. Chem. 52, 3510-3532.

Momma, K. \& Izumi, F. (2011). J. Appl. Cryst. 44, 1272-1276.

Morrison, J. M., Moore-Shay, L. J. \& Burns, P. C. (2011). Inorg. Chem. 50, 2272-2277.

Nguyen, Q. B., Liu, H.-K., Chang, W. J. \& Lii, K.-H. (2011). Inorg. Chem. 50, 4241-4243.

O'Hare, P. A. G., Lewis, B. M. \& Nguyen, S. N. (1988). J. Chem. Thermodyn. 20, 1287-1296.

Olds, T. A., Lussier, A. J., Oliver, A. G., Petříček, V., Plášil, J., Kampf, A. R., Burns, P. C., Dembowski, M., Carlson, S. M. \& Steele, I. M. (2017). Mineral. Mag. 81, 403-409.

Petříček, V., Dušek, M. \& Palatinus, L. (2014). Z. Kristallogr. 229, 345-352.

Petř́íček, V., Dušek, M. \& Plášil, J. (2016). Z. Kristallogr. 231, 583599.

Plášil, J. (2014). J. Geosci. 59, 99-114.

Plášil, J. (2017). Am. Mineral. 102, 1771-1775.

Plášil, J. (2018). Eur. J. Mineral. 30, 237-251.

Rigaku Oxford Diffraction (2017). CrysAlis CCD, CrysAlis RED and CrysAlis PRO. Oxford Diffraction Ltd, Yarnton, Oxfordshire, UK.

Robinson, K., Gibbs, G. V. \& Ribbe, P. H. (1971). Science, 172, 567570.

Rojo, H., Scheinost, A. C., Lothenbach, B., Laube, A., Weiland, E. \& Tits, J. (2018). Dalton Trans. 47, 4209-4208.

Schindler, M. \& Hawthorne, F. C. (2004). Can. Mineral. 42, 16011627.

Serezhkin, V. N. (2007). In Structural Chemistry of Inorganic Actinide Compounds, edited by S. V. Krivovichev, P. C. Burns and I. G. Tananaev, pp. 31-64. Elsevier.

Serezhkin, V. N., Kovba, L. M. \& Trunov, V. K. (1973). Kristallografiya, 18, 514-517 (in Russian).

Sheldrick, G. M. (2015). Acta Cryst. A71, 3-8.

Stritzinger, J. T., Alekseev, E. V., Polinski, M. J., Cross, J. N., Eaton, T. M. \& Albrecht-Schmitt, T. E. (2014). Inorg. Chem. 53, 52945299.

Unruh, D. K., Baranay, M., Baranay, M. \& Burns, P. C. (2010). Inorg. Chem. 49, 6793-6795.

Wronkiewicz, D. J., Bates, J. K., Gerding, T. J., Veleckis, E. \& Tani, B. S. (1992). J. Nucl. Mater. 190, 107-127.

Wronkiewicz, D. J., Bates, J. K., Wolf, S. F. \& Buck, E. C. (1996). J. Nucl. Mater. 238, 78-95.

Wu, S., Ling, J., Wang, S., Skanthakumar, S., Soderholm, L., AlbrechtSchmitt, T., Alekseev, E. A., Krivovichev, S. V. \& Depmeier, W. (2009). Eur. J. Inorg. Chem. 2009, 4039-4042.

Zachariasen, W. H. (1978). J. Less-Common Met. 62, 1-7. 